Ife Journal of Science vol. 20, no. 3 (2018)

\title{
CHANGES IN LEAF MORPHOLOGICAL AND ANATOMICAL CHARACTERS OF SOME PLANT SPECIES IN RESPONSE TO GEMSTONE MINING IN SOUTHWESTERN NIGERIA
}

\author{
${ }^{1}$ Christianah Sade Ogundare, ${ }^{2}$ Mahboob Adekilekun Jimoh and ${ }^{1}$ Sefiu Adekilekun Saheed* \\ ${ }^{1}$ Department of Botany, Obafemi Awolowo University, Ile-Ife, Osun State, Nigeria. \\ ${ }^{2}$ Department of Plant Biology, Osun State University, Osogbo, Osun State, Nigeria. \\ *E-mail of Corresponding Author: saheed@oauife.edu.ng \\ (Received: $6^{\text {th }}$ June, 2018; Accepted: 19 ${ }^{\text {th }}$ July, 2018)
}

\section{ABSTRACT}

\begin{abstract}
The responses of seven selected plant species to gemstone mining activities were investigated based on data obtained from exo- and endo- morphology of the leaves with the aim of establishing the responses of the plant species to gemstone mining pollution and the underlining mechanism which could possibly explain such responses. Both qualitative and quantitative methods, using visual and microscopic assessment were adopted. Results of the foliar morphology showed that most of the plant species had significant increase $(p<0.05)$ in the leaf area and petiole length in polluted sites compared to those from unpolluted site though with noted variations in others. The observed morphological responses are associated with corresponding significant increase $(\mathrm{p}<0.05)$ in stomata frequency, epidermal cell number, glandular and non-glandular trichome frequency and length, cuticle thickness, upper and lower epidermis. However, characters such as stomata size and palisade mesophyll tissue were significantly $(\mathrm{p}<0.05)$ reduced. We conclude based on the data obtained in this study that plants generally respond differently to pollution due to mining through either increase or reduction in some of their external (leaf area and petiole length) and internal features. These depict adaptive mechanisms employed by the plants in order to cope with polluted environments.
\end{abstract}

Keywords: Plant morphology, Plant anatomy, Mining pollution, Leaf area, Petiole.

\section{INTRODUCTION}

Mining activities is the second largest source of heavy metal contamination in soil after sewage sludge (Singh et al., 2005; 2011). Pollution from metal mining is one of the most serious environmental problems in our contemporary environment (Singh et al., 2011; Chen et al., 2018). Generally, mine tailings are a major source of contaminants of heavy metals in water, soil and biota (Nwuche and Ugoji, 2008; Tiwari and Lata, 2018). Also, soil contamination with heavy metals may cause changes in the composition of soil microbial community, thereby adversely altering soil characteristics (Kurek and Bollag, 2004; Fashola et al., 2016).

Several metals are essential for biological systems which must be present in the soil within a certain concentration limit (Shahid et al., 2015). Where such metals are present at high concentrations, they can act in a deleterious manner to plants. Uptake and accumulation of some metals at higher concentration can have cytotoxic effects in some plants species, thereby causing structural and ultra-structural changes which can affect growth and physiological well-being of plants
(Panuccio et al., 2009; Hassan et al., 2017). For example, studies have shown that excessive concentrations of heavy metals in plants can cause oxidative stress and stomatal resistance (Zhao et al., 2000; Han et al., 2004). It can also affect photosynthesis and chlorophyll florescence processes, both of which are essential for plant nutrition (Shah et al., 2009). Lead (Pb), for instance, is one of the heavy metals that is known to induce changes in leaf epidermal structures by causing a reduction in the cell size, bring about abundant wax coating, increase frequency of stomata and trichomes per unit area and simultaneous reduction in the sizes of the guard cells (Gomes et al., 2011).

Plants have developed a variety of strategies to respond to changes in their environment. Those growing on or around abandoned or currently mined sites and on naturally metal-enriched soils are known to be genetically tolerant to high metal concentrations (Xiong et al., 2014; Pierart et al., 2015). Morphologically, it has been reported that heavy metal toxicity could lead to decrease in total number and sizes of leaves as well as cause chlorosis and necrosis of leaves, which altogether result in decreased photosynthetic capacity of 
plants (Pierart et al., 2015; Amari et al., 2017). The root system is particularly affected by heavy metal contamination being part of the plant in direct contact with the contaminated soil. In the roots, heavy metals have been shown to be accumulated and translocated in the cell wall, exodermis and endodermis. They constitute barrier to overall movement of mineral ions normally required by plants (Lux et al., 2004). Heavy metal-induced root responses have been previously described in some plant species (Marques et al., 2011). These responses include decreases in root hair numbers, damage to epidermal and cortical cells and lack of pith formation and differentiation in the stele (Singh et al., 2007). These studies have pointed out that these responses vary with different plants and with different metal pollutants.

Several studies have been carried out to highlight the effects of mining on plants especially in many developed countries. However, there is limited information on the mechanism (structurefunction) underlying the effects of soil contamination on plants growing in environments contaminated with heavy metals, particularly in developing countries like Nigeria. Gemstone mining is a type of artisanal mining in Nigeria, which involves people of different cadres, employing both crude and advanced technology, portending grave damage and contamination to the environment. On this basis, there is the need to carry out a detailed study such as this, in order to bridge the knowledge gaps. This study is expected to elucidate specific adaptive characteristics employed by different species of plants to heavy metals pollution.

\section{MATERIALS AND METHOD}

\section{Study Site}

The study site is the gemstone mining site located in Awo, Egbedore Local Government Area of Osun State, southwestern Nigeria, where mining of gemstones is carried out at subsistence level. It is situated on kilometer 75 along Iwo-Oshogbo road (Figure 1). The site was subdivided into three sites: Mined (Longitude $7^{\circ} 77^{\prime} 027^{\prime \prime} \mathrm{N}$ Latitude $4^{\circ}$ 40' 489"E), abandoned (Longitude $7^{\circ} 77^{\prime} 112^{\prime \prime} \mathrm{N}$ Latitude $4^{\circ} 40^{\prime} 483^{\prime \prime} \mathrm{E}$ ) and an unmined (control) site (Longitude $7^{\circ} 76^{\prime}$ 986"N Latitude $4^{\circ} 40^{\prime}$ $448 " \mathrm{E})$.

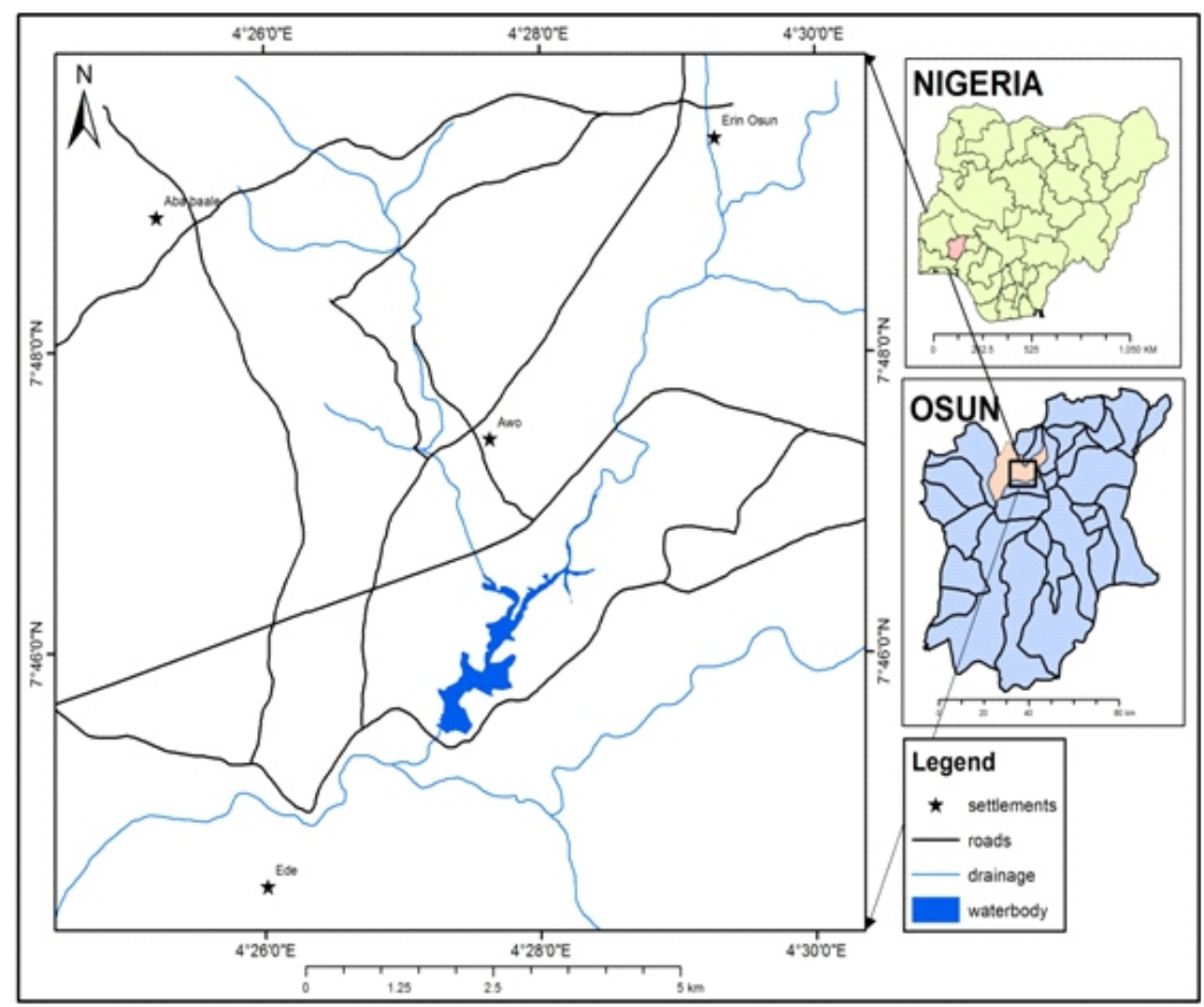

Figure 1: Location Map of the Study Site in Awo, Egbedore Local Government Area of Osun State, Nigeria. 


\section{Plant Materials}

Seven plants species belonging to four angiospermic families found in the three sites were selected for this study. They are Hyptis suaveolens (L.) Poit. (Lamiaceae); Trema orientalis (L.) Blume (Ulmaceae); Waltheria indica (L.) (Sterculiaceae); Aspilia Africana (Pers.) C.D. Adams, Chromolaena odorata (L.) R.M. King and H.E. Robins, Emilia coccinea (Sims.) G. Don and Tithonia diversifolia (Hemsl.) A. Gray, (Asteraceae). Identification of the plant specimens were carried out at the Department of Botany, Obafemi Awolowo University Herbarium (IFE) and Forestry Herbarium, Ibadan (FHI). The abbreviations employed follow Holmgren et al. (1981). In addition, Flora of West Tropical Africa by Hutchinson and Dalziel (1972) was consulted for further clarification.

\section{Data Collection}

Fresh leaves at the same leaf stage, with regards to the same level of insertion on the stem were collected randomly from plants of the same chronological age (i.e. at the same level of branching). Quantitative morphological characters such as the petiole length and leaf area were measured. Petiole length was measured using meter rule while leaf area was calculated using the Pandey and Singh (2011) method. For foliar epidermal study, sizeable portions of mature fresh leaves for each species studied were cut from the median part of well expanded leaves following previously established protocols (Saheed and Illoh, 2010; Ogundare and Saheed, 2012). The leaf portions were placed in petri-dish containing concentrated nitric acid (95\%) within 5-24 h of cutting, depending on the nature of the leaf. Both adaxial and abaxial surfaces were studied by lifting the unrequired surfaces with forceps. The epidermal peels from each of adaxial and abaxial surfaces were separately placed on clean glass slides stained with Safranin O and mounted in 25\% glycerine. Data were obtained for stomata frequency (average frequency of stomata per square ocular micrometer was calculated), stomata size, giant stomata size (these are stomata that are bigger in size than the normal stomata and are fewer in number) and trichome frequency and length.

Transverse sections of the leaves were cut using a $\mathrm{R}$. JUNG Heidelberg Rotary microtome (Model: $1130 /$ BIOCUT) set at $20 \mu \mathrm{m}$ thickness. Slides were prepared by staining the sections in $1 \%$ aqueous solution of Safranin O for 4-5 minutes, rinsed in 23 changes of water, stained again with alcian blue for 4-5 minutes, rinsed in 2-3 changes of water and dehydrated through several grades of alcohol until lastly absolute alcohol was used. The dehydrated materials were then mounted in $25 \%$ glycerine on clean glass slides with the edges of covered slip sealed with nail varnish for microscopic studies. Data were collected for thickness of the cuticle, epidermis, palisade and spongy mesophyll tissues. Observations of the cut sections were done with the aid of light microscope (Model Leica DM 500) and microphotographs of important anatomical characters were made with the aid of an Amscope camera attached to the ACCUScope microscope. All quantitative characters were measured using the calibrated ocular micrometer already inserted in the eye-piece of the microscope. Twenty different measurements were obtained for each character per species $(n=20)$ while basic statistical methods were applied for result interpretation.

\section{RESULTS}

The results of quantitative morphological characters of the leaf area and petiole length of the plant species studied are presented in figure 2 . The plant species showed variation in both characters across the sites, all of which are species-specific. The general pattern of the data obtained revealed a significant increase in leaf area and petiole length of plant species growing in mined and abandoned sites in comparison to those in the unmined control site (Figure 2). However, there are variations to this pattern in some instances. For example, the mean leaf area of $C$. odorata reduced significantly $(\mathrm{p}<0.05)$ from $42.34 \pm 2.82 \mathrm{~cm}^{2}$ in the unmined site to 35.38 $\pm 3.41 \mathrm{~cm}^{2}$ in the mined but abandoned site and $34.34 \pm 2.94 \mathrm{~cm}^{2}$ in the currently mined site. However, the reduction in leaf area was not significantly different from abandoned to the unmined sites (Figure 2). Petiole length of $T$. diversifolia of unmined site reduced significantly $(p<0.05)$ from $4.52 \pm 0.27 \mathrm{~cm}$ to $4.33 \pm 0.38 \mathrm{~cm}$ in abandoned site and $2.52 \pm 0.29 \mathrm{~cm}$ obtained in the mined site. In $W$. indica, the mean petiole length reduced across the three sites with $1.92 \pm 0.19 \mathrm{~cm}$ in the unmined site, $1.85 \pm 0.12 \mathrm{~cm}$ in the abandoned site and $1.76 \pm 0.13 \mathrm{~cm}$ in mined site. The reductions encountered were not significantly different $(p<0.05)$ across the three study sites (Figure 2). 

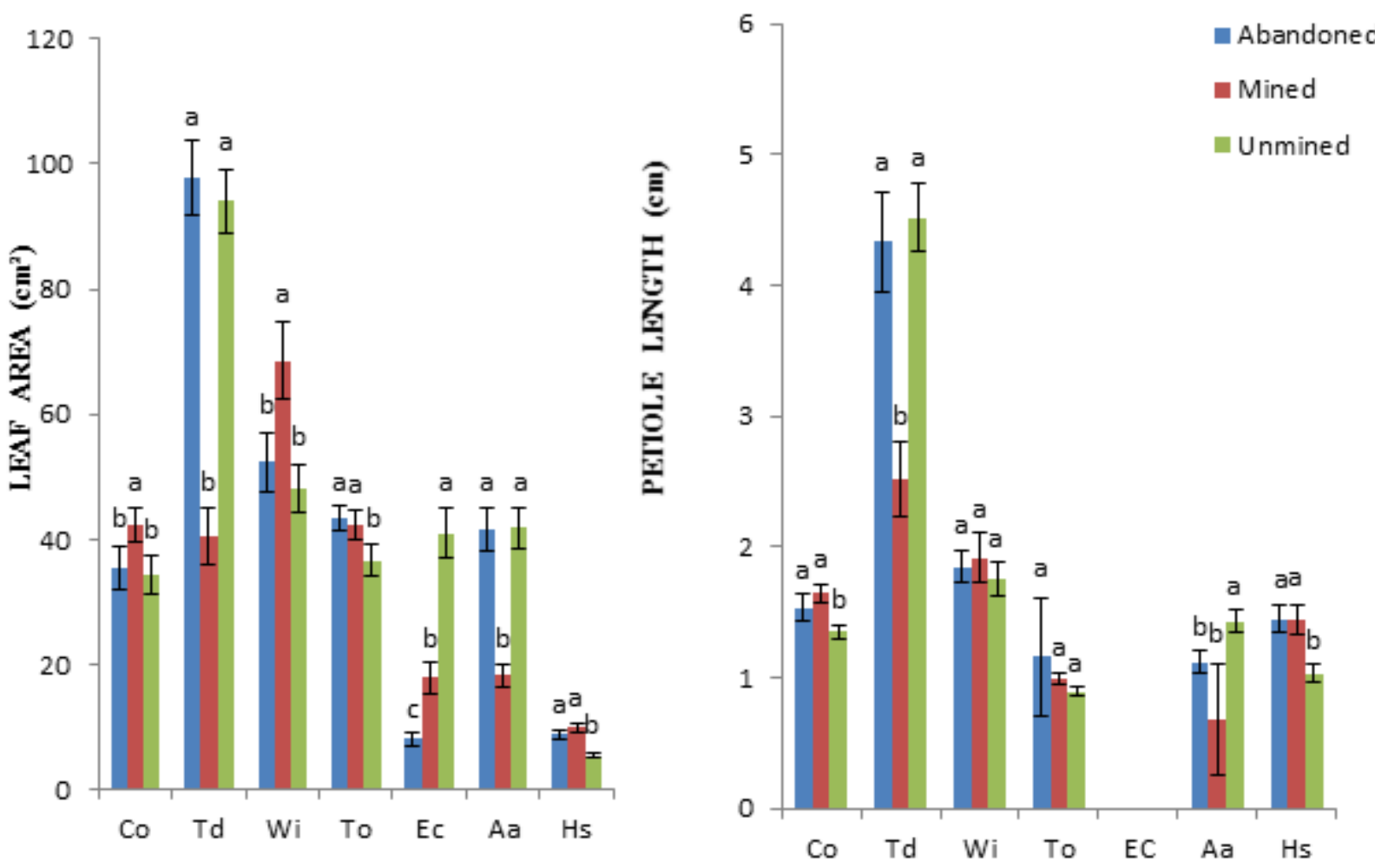

Figure 2: A - Mean Leaf Area; B - Mean Petiole Length of plant species across the Three Study Sites. Vertical bars are the SE. Similar letters on top corresponding bars indicate statistically non-significant differences at $\mathrm{p}<0.05$ for each species

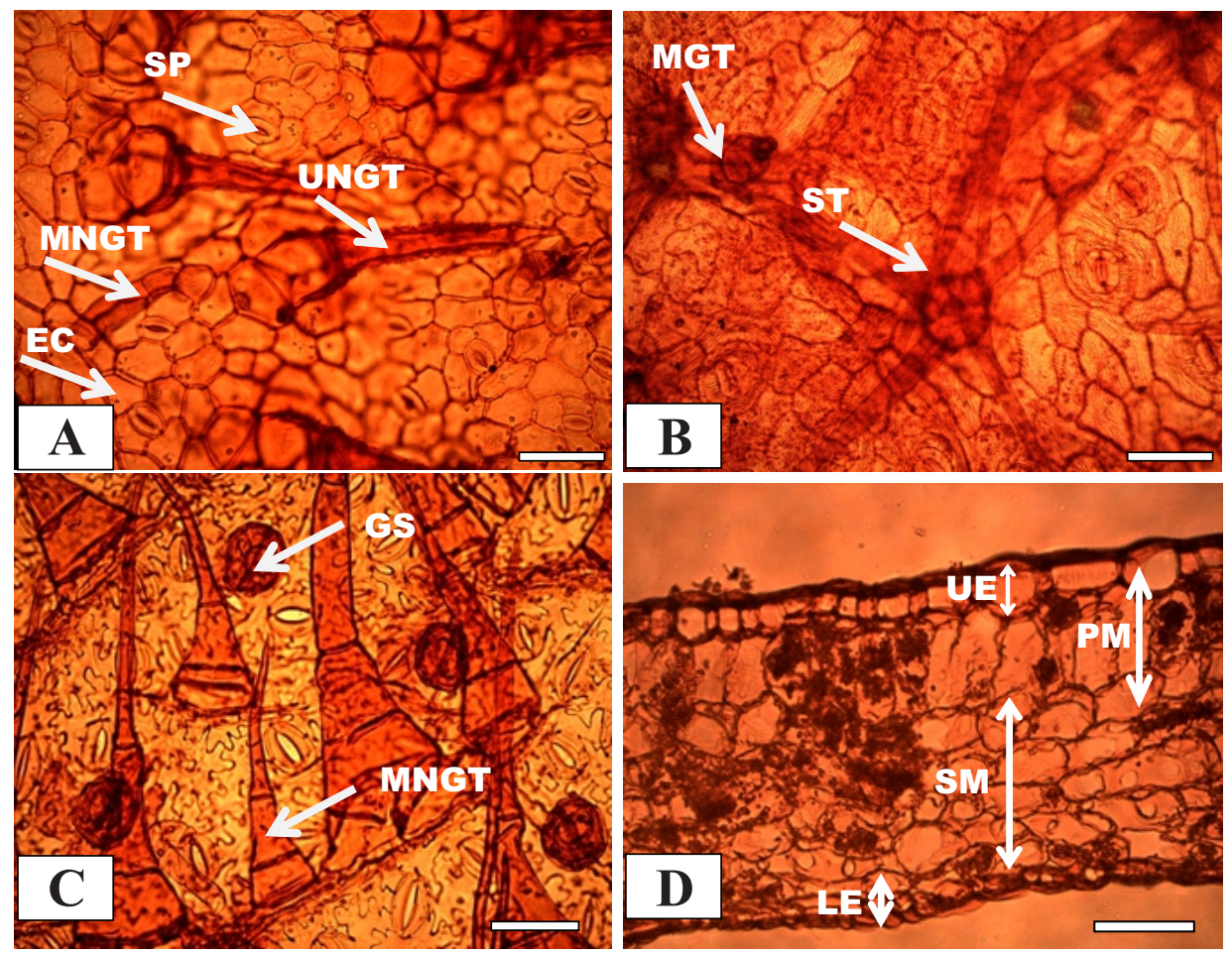

Figure 3: Leaf Epidermal Surface of A - A. Africana (adaxial), B - W. Indica (adaxial) and C - T. diversifolia (abaxial); D - Transverse Section of the Leaf of E. coccinea Showing Typical Characters Measured

Legend: $\mathrm{SP}=$ Stomata pore; $\mathrm{EC}=$ Epidermal cell; UNGT $=$ Unicellular non glandular trichome; MNGT = Multicellular non glandular trichome; MGT= Multicellular glandular trichome; ST = Stellate trichome; PM= Palisade Mesophyll; UE = Upper Epidermis; LE= Lower Epidermis; SM= Spongy Mesophyll. Scale A = 55 m; B $=150 \mu \mathrm{m} ; \mathrm{C}=30 \mu \mathrm{m} ; \mathrm{D}=35 \mu \mathrm{m}$. 
Examination of the leaf epidermal characters generally revealed significant increase in stomatal frequency, epidermal cell number and trichome frequency on both surfaces in most of the plant species growing on mined and abandoned as compared to control sites. This trend is similar to what was observed with the morphological data. Conversely, reduced stomata size was observed in the three sites. Comparatively, for stomatal frequency, significant increase $(\mathrm{p}<0.05)$ was recorded for $T$. diversifolia with $4.95 \pm 0.48 \mathrm{~mm}$ obtained in the unmined site, $10.45 \pm 0.61 \mathrm{~mm}^{2}$ in the mined site and $16.55 \pm 0.41 \mathrm{~mm}^{2}$ in the abandoned site. However, the reduction was not significantly different $(p<0.05)$ for the three sites in C. odorata on the adaxial surface (Table 1). On the abaxial surface, significant increase $(p<0.05)$ was recorded in the stomata frequency in $T$. diversifolia from $16.35 \pm 0.72 \mathrm{~mm}^{2}$ in the unmined to $19.50 \pm 0.66 \mathrm{~mm}^{2}$ in the mined to $21.35 \pm 0.67$ $\mathrm{mm}^{2}$ in abandoned sites (Table 2). In C. odorata however, there was significant $(\mathrm{p}<0.05)$ increase in the stomatal frequency from $12.50 \pm 0.93 \mathrm{~mm}^{2}$ of the unmined site and $13.50 \pm 0.89 \mathrm{~mm}^{2}$ in the mined site and $16.75 \pm 0.56 \mathrm{~mm}^{2}$ in the abandoned site. There was no significant difference $(p<0.05)$ in the stomatal frequency values of mined and unmined sites (Table 2). Similar trends were recorded for other characters (epidermal cell number, stomatal size, giant stomatal number, epidermal cell length, epidermal cell width, giant stomata size, non-glandular trichome number, glandular trichome number, non-glandular trichome length and glandular trichome length) in other species (Tables 1 and 2).

The results from the internal leaf tissues investigated equally revealed a corresponding significant increase $(p<0.05)$ in most of the characters examined which include the mean cuticle thickness, upper and lower epidermis. A significantly reduced $(\mathrm{p}<0.05)$ palisade mesophyll cells occurs in most of the plant species growing on mined and abandoned sites when compared to control unmined site (Table 3). For instance, the upper cuticle of $C$. odorata increased significantly $(\mathrm{p}<0.05)$ from $2.50 \pm 0.00 \mu \mathrm{m}$ in unmined to 3.00 $\pm 0.33 \mu \mathrm{m}$ in abandoned and to $4.00 \pm 0.55 \mu \mathrm{m}$ in mined sites (Table 3). The thickness of upper epidermis of $W$. indica was found to increase significantly $(p<0.05)$ from $22.75 \pm 1.42 \mu \mathrm{m}$ in unmined site to $27.00 \pm 0.62 \mu \mathrm{m}$ in abandoned site and $44.75 \pm 2.46 \mu \mathrm{m}$ in mined site. Also, $H$. suaveolens reduced significantly $(\mathrm{p}<0.05)$ in the thickness of palisade from $67.75 \pm 4.62 \mu \mathrm{m}$ (unmined) to $65.75 \pm 2.27 \mu \mathrm{m}$ (mined) to $57.00 \pm$ $1.82 \mu \mathrm{m}$ (abandoned), however, there was no significant difference $(p<0.05)$ between unmined and mined sites. The results obtained for other characters (thickness of spongy mesophyll, thickness of lower cuticle and thickness of lower epidermis) in other species are presented as shown in Table 3. 


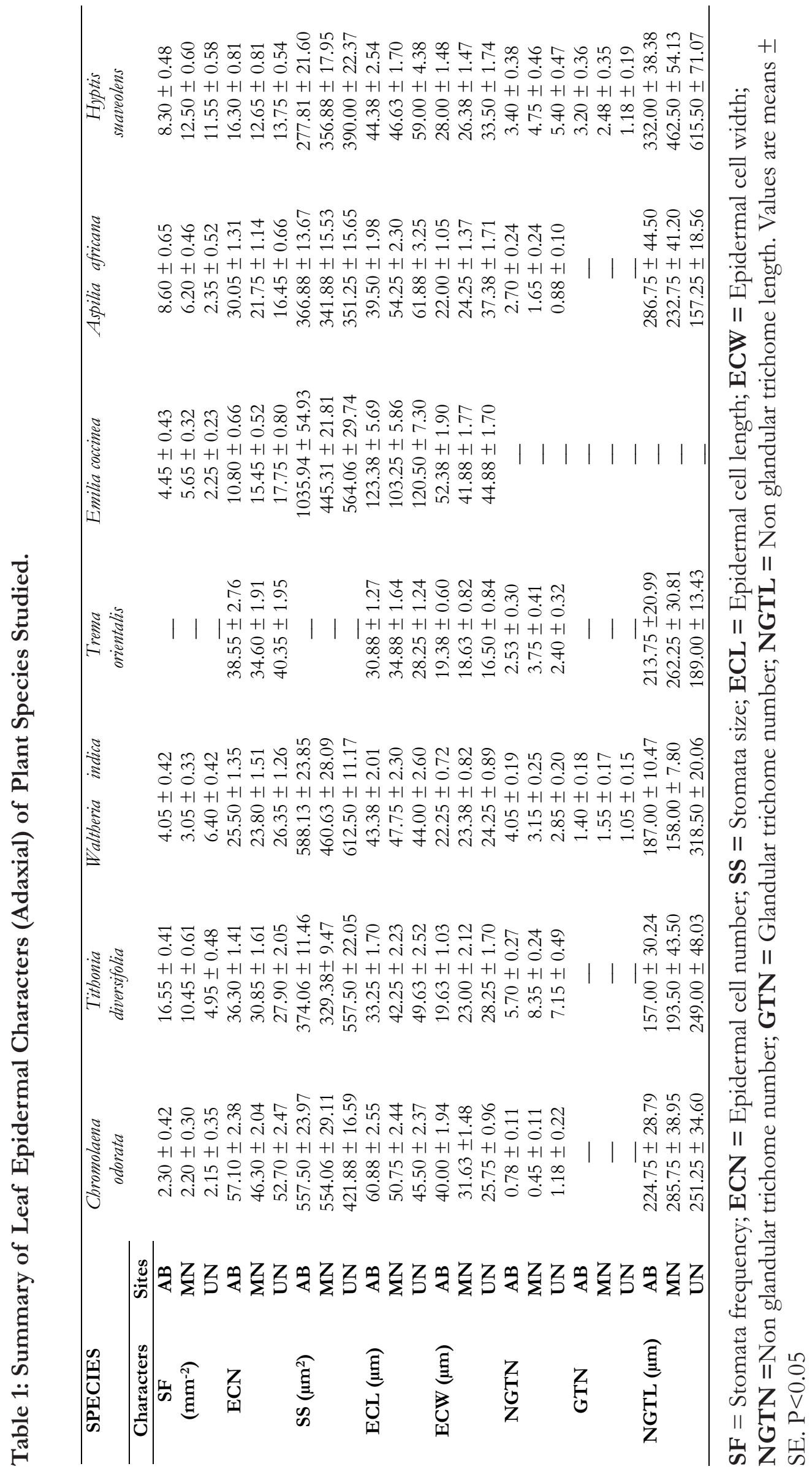


Ogundare et al.: Changes in Leaf Morphological and Anatomical Characters of Some Plant

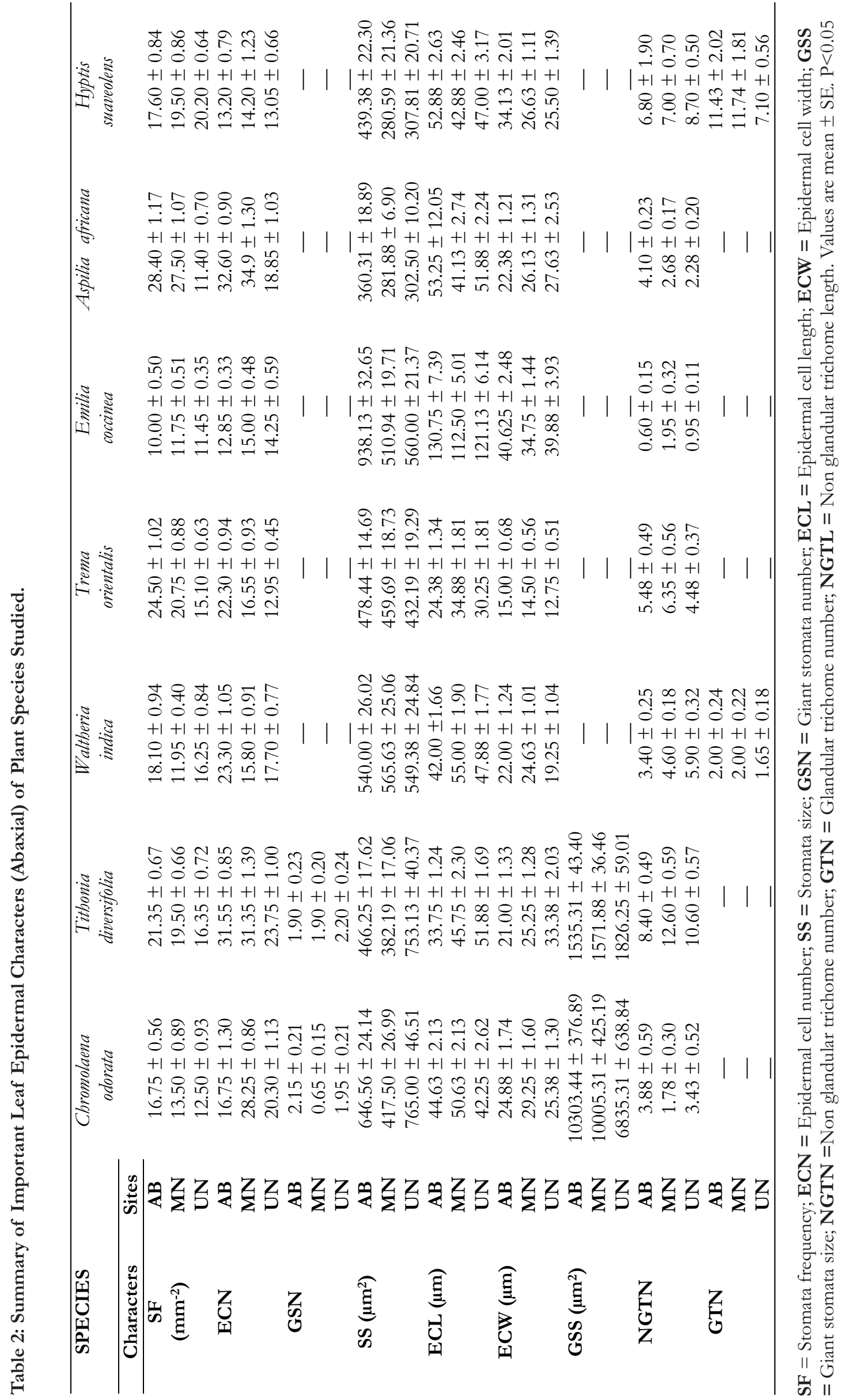




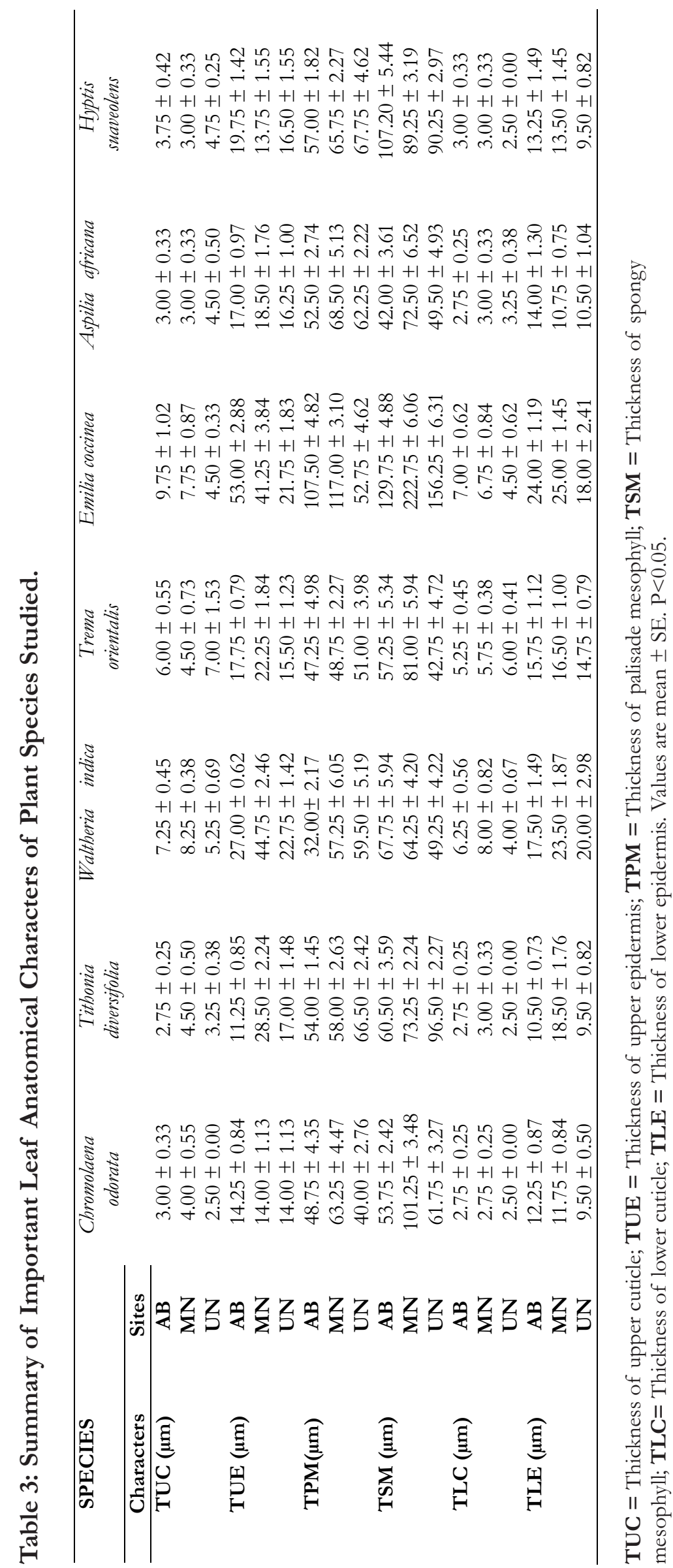




\section{DISCUSSION}

Plants exposed to pollutants from mining respond by initiating a number of survival strategies which allow them to develop and grow on such polluted environment. These strategies evidently engender alterations to a number of morphological attributes of such plants. In addition, these responses have been shown to be species-specific with different plant species responding differently to even the same level of pollution (Shahid et al., 2015; Fashola et al., 2016; Tiwari and Lata, 2018). However, understanding the mechanism of the survival strategies or adaptive modifications of these plants in response to heavy metal pollution is very crucial. Morphological characters investigated in this study focused on changes that occur to leaves and petioles. Morphological features and physiological responses are linked to adaptive characteristics of plants in stressed environments (Amari et al., 2017). Data from this study shows that generally a significant increase $(p<0.05)$ in leaf area and petiole length occurs in plants growing in polluted sites (mined and abandoned sites) when compared to those growing in the unpolluted, unmined environment. This shows that plants growing in currently mined area would have to increase their leaves and petioles in other to cope with the effect of the pollutants resulting from fresh mining activities.

Singh and Agrawal (2010) and Tran et al. (2013) have reported that Beta vulgaris and Psidium sativum responded to heavy metal pollution by significantly increasing their leaf area. However, a decrease in these parameters was observed in the current study in $T$. diversifolia and $A$. africana as a result of exposure to heavy metals. An interesting outcome of this study is that E. coccinea, a sessile, non petiolate plant species appears to be the only species worst hit with the effects of mining activities as it displayed a continuous decrease in leaf area. This response perhaps suggests that $E$. coccinea may not be able to survive for a long time if mining activities were sustained in the sites. Reduction in leaf area and other plant parts in response to heavy metal or air pollution have been reported in a number of plant species and these have been considered as adaptive advantages which enable leaves to develop and function in habitats marked by such pollution (Stevovic et al. 2010; Ekpemerechi et al., 2017). This diverse response of the plant species further shows that responses to heavy metal pollution and changes to the environment are species-specific (Sumiahadi and Acar, 2018).

The observed changes in the morphology of the plants in various sites where they grow are expected to be as a result of changes in respective internal tissues. Corresponding changes found to occur in internal tissues of those plants could best be used to explain the mechanism that underlies the observed morphological changes in these plants. For instance, with the exception of few species, significant increase $(p<0.05)$ were recorded in most of the epidermal characters including stomatal frequency, epidermal cell number, glandular and non-glandular frequency and length in heavy metal polluted environments (mined and abandoned sites) when compared to unpolluted (unmined) site on both epidermal surfaces. It is only stomata size that showed corresponding significant reduction $(p<0.05)$. Giant stomata (stomata that are bigger than normal types) were found only on the abaxial surface in C. odorata and T. diversifolia among other species studied and their frequencies and sizes were significantly reduced $(p<0.05)$ in the two species in polluted sites when compared to control.

The decrease in the size of stomata is thought to be an avoidance mechanism against the inhibitory effect of pollutants on physiological activities of the plant such as photosynthesis (Gomes et al., 2011). These modifications are important response to the environmental stress which affected plants used in controlling the absorption of pollutants (Gostin, 2009; Hassan et al., 2017). The decrease observed in the sizes of stomatal aperture as a response to heavy metal pollution is in line with the hypothesis that metals induce water stress (Rucin'ska-Sobkowiak, 2016). Therefore, closed stomata of the leaf are expected to result in a slower rate of diffusion due to greater diffusion gradient of water vapors (Singh et al., 2011; Rucin'ska-Sobkowiak, 2016). The various effects of water deficit seen on stomata structure are clear mechanisms which enable plants survive in stress conditions (Sumiahadi and Acar, 2018).

Another important outcome of this study is the 
general increase in the epidermal cell characteristics in polluted sites when compared to the control, though other variations (reduction or no response) were equally observed. Epidermal cells have been reported to prevent leaves from excessive sunlight, as well as control transpiration in plant species (Nurtjahya et al., 2011). This suggests that specific response of each plant species has to do with the peculiarity of the species as an individual. However, the reduction observed in the epidermal cells of some plants growing on mined site is an important mechanism of controlling transpiration rate in stressed environment (Marques et al., 2011; Ekpemerechi et al., 2017).

The usefulness of trichome in plants growing in heavy metals contaminated environment has been reported by many researchers. Many specific functions have been ascribed to development of trichomes such as protection against herbivores and UV light, storage of toxic metal ions and increased freezing tolerance (Rafia et al., 2009). In this study, non-glandular and glandular trichomes were encountered and the result showed generally that their characteristics increased significantly $(p<0.05)$ on the two leaf surfaces in plants growing on mined and polluted sites, when compared to those in unmined sites (control) though with variations in species like $C$. odorata, $T$. diversifolia and $H$. suaveolens. According to Rafia et al. (2009), the observed significant increases in trichome frequency of plants growing in $\mathrm{Pb}$ polluted soil serve as means of self-defence developed by plants under stressed condition. Increase in trichomes and epidermal cell modifications in plants were earlier reported to enable stomata remain open over a wide range of water deficits (Singh et al., 2011). In addition, deficiencies in water uptake as well as accumulation of heavy metals have been reported to produce greater leaf trichome densities depending on the species of plants involved (Rafia et al., 2009).

Results obtained from the current study clearly indicate that internal tissues of the leaves of all investigated species experienced either significant increase or decrease in the size of internal anatomical characters. This is a clear indication that responses of plants to mining pollution are species-specific. The cuticles (upper and lower) increased significantly $(\mathrm{p}<0.05)$ in plant species growing on mining-polluted sites as compared to the unmined control with the exception of $T$. orientalis and $H$. suaveolens where the cuticles reduced significantly. The presence of thick cuticle and dense cell structure are part of the modifications possessed by plant species for water conservation and also to withstand environmental stress (Gomes et al., 2011; Tiwari and Lata, 2018). Therefore, any specific or predictable alteration in cuticle due to heavy metal mining could serve as diagnostic marker as well as a response of the affected plant to mining. Significant increase in the leaf epidermis has been demonstrated to be characteristics of plants growing in polluted environments when compared to those from unpolluted site (Gomes et al., 2011; Xiong et al., 2014; Pierart et al., 2015). Data from this study corroborates the work of Iqbal (1985) which showed significant reduction in palisade and spongy parenchyma cells in leaf of white clover of a polluted population. In addition, exposures to heavy metals lead to reduction and collapse in the size of mesophyll cells (Sridhar et al., 2005; Zhao et al., 2000). This phenomena in plants growing on mining environment is suggested to be adaptive measures to withstand drought stress (Gomes et al., 2011), which has been indicated to increase the mechanical tissues for plants in order to be able to withstand effects of drought-related mechanical stress.

In conclusion, data from this study has elucidated modifications to some morphological and anatomical characters of leaves of investigated plant species due to gemstone mining pollution. Specifically, this study indicates that plants generally respond to pollution from mining by increasing the sizes of their leaves and petioles, some of which are associated with corresponding increase in the internal tissues of the leaf. Plant species that are better adapted to miningassociated pollution in this study include $C$. odorata, $T$. diversifolia, $W$. indica, $T$. orientalis and $H$. suaveolens while E. coccinea did not. The responses displayed by the plants could be a strategy of coping with heavy metal pollution with respect to regulation of water use efficiency. This conclusion is not oblivious of the fact that some plant species studied are at variance to the itemized responses 
and that the responses shown by plants' leaves to certain abiotic stresses resulting from gemstone mining can be species-specific. Therefore, the investigated plant species can be further scrutinized for use in studies of environmental pollution.

\section{REFERENCES}

Amari, T., Ghnaya, T., and Abdelly, C. 2017. Nickel, cadmium and lead phytotoxicity and potential of halophytic plants in heavy metal extraction. South African Journal of Botany, 111:99-110.

Chen Y., Jiang X., Wang Y., and Zhuang D. 2018. Spatial characteristics of heavy metal pollution and the potential ecological risk of a typical mining area: A case study in China. Process Safety and Environmental Protection, 113: 204-219.

Ekpemerechi, S.E., Ajao, A.A., Jimoh, M.A. and Saheed, S.A. 2017. Variation in leaf anatomical characters in response to air pollution in some Euphorbiaceae species. West African Journal of Applied Ecology, 25(1):21-31.

Fashola, M.O., Ngole-Jeme, V.M. and Babalola, O.O. 2016. Heavy Metal Pollution from Gold Mines: Environmental Effects and Bacterial Strategies for Resistance. International Journal of Environmental Research and Public Health, 13: 1047.

Gomes, M.P., Marques, T.C.L.L.S.M., Nogueira, M.O.G., Castro, E.M. and Soares, A.M. 2011. Ecophysiological and anatomical changes due to uptake and accumulation of heavy metal in Brachiaria decumbens. Scientia Agricola, 68: 566-573.

Gostin, N.I. 2009. Air Pollution Effects on the Leaf Structure of some Fabaceae Species. Notulae Botanicae Horti Agrobotanici. ClujNapoca, 37(2): 57-63.

Han, F.X., Sridhar, M.B.B., Monts, D.L. and Su, Y. 2004. Phytoavailability and toxicity of trivalent and hexavalent chromium to Brassica juncea L. Czern. New Phytologist, 162: 489-499.

Hassan, T. U., Bano, A., and Naz, I. 2017. Alleviation of heavy metals toxicity by the application of plant growth promoting rhizobacteria and effects on wheat grown in saline sodic field. International Journal of
Phytoremediation, 19: 522-529.

Holmgren, P.K., Keuken, W. and Schofield, E.K. 1981. Index Herbariorum. Part 1 The Herbaria of the World. Utrecht, Oosthoek, Scheltema \& Holkema.

Hutchinson, J. and Dalziel, J.M. 1972. Flora of West Tropical Africa. Crown Agent for Overseas Government and Administration Nill Bank London S. Vol. 1.

Iqbal, M.Z. 1985. Cuticular and anatomical studies of white clover leaves from clean and airpolluted areas. Pollution Research, 4: 59-61.

Kurek, E. and Bollag, J.M. 2004. Microbial immobilization of cadmium released from CdO in the soil. Biogeochemistry, 69(2): 227-239.

Lux, A.A., Sottnikova, A., Opatrna, J. and Greger, M. 2004. Differences in structure of adventitious roots in Salix clones with contrasting characteristics of cadmium accumulation and sensitivity. Physiologia Plantarum, 120: 537-545.

Marques, T.C.L.L.S.M., Soares, A.M., Gomes, M.P. and Martins, G. 2011. Physiological and anatomical responses of Eucalyptussed.edlings exposed to cadium. Revista Árvore, 25: 997-1006.

Nurtjahya, E., Robika, R., and Dorly, D. 2011. Can anatomical and physiological characters predict plant adaptation on tin-mined land in Bangka Island? Proceedings of the 6th International Conference on Mine Closure, A.B. Fourie, and M. Tibbett and A. Beersing (eds), Alberta, Canada, Australian Centre for Geomechanics, Perth, pp. 75-83.

Nwuche, C.O. and Ugoji, E.O. 2008. Effects of heavy metal pollution on the soil microbial activity. International Journal of Environmental Science and Technology, 5(3): 409-414.

Ogundare, C.S. and Saheed, S.A. 2012. Foliar epidermal characters and petiole anatomy of four species of Citrus L. (RUTACEAE) from south-western Nigeria. Bangladesh Journal of Plant Taxonomy, 19(1): 25-31.

Pandey, S.K. and Singh, H. 2011. A simple, costeffective method for leaf area estimation. Ecosystem analysis Laboratory, Dept. of Botany, Hindu University, Varanasi 221005, India. Journal of Botany. Article ID 
658240, 6pages.

Panuccio, M. R., Sorgona, A., Rizzo, M., and Cacco, G. 2009. Cadmium adsorption on vermiculite, zeolite and pumice: batch experiment studies. Journal of EnvironmentalManagement, 90:364-374.

Pierart, A., Shahid, M., Séjalon-Delmas, N., and Dumat, C. 2015. Antimony bioavailability: knowledge and research perspectives for sustainable agricultures. Journal of Hazardous Materials, 289: 219-234.

Rafia, A., Saba, H., Hajra, N., Farha, A. and Marina, R. 2009. A viable alternative mechanism in adapting the plants to heavy metal environment. Pakistan Journal of Botany, 41(6): 2729-2738.

Rucin'ska-Sobkowiak R. 2016. Water relations in plants subjected to heavy metal stresses. Acta Physiologiae Plantarum, 38: 257.

Saheed, S.A. and Illoh, H.C. 2010. A taxonomic study of some species in Cassinae (Leguminosae) using leaf epidermal characters. Notulae Botanicae Horti Agrobotanici Cluj-Napoca, 38: 21-27.

Shah, B.A., Shah, A.V. and Singh, R.R. 2009.Sorption isotherms and kinetics of chromium uptake from wastewater using natural sorbent material. International Journal of Environmental Science and Technology, 6 (1): 77-90.

Shahid, M., Khalid, S., Abbas, G., Shahid, N., Nadeem, M., Sabir, M. 2015. "Heavy metal stress and crop productivity," in Crop Production and Global Environmental Issues, ed. K. R. Hakeem (Cham: Springer International Publishing), pp1-25.

Singh, A. and Agrawal, M. 2010. Effects of municipal waste water irrigation on availability of heavy metals and morphophysiological characteristics of Beta vulgaris L. Journal of Environmental Biology, 31(5): 727-736.

Singh, A.N., Zeng, D.H. and Chen, F.S. 2005. Heavy metals concentration in redeveloping soil of mine spoil under plantation of certain native woody species in dry tropical environment, India. Journal of Environmental Science, 17(1):168-174.

Singh, H.P., Batish, D.R., Kohli, R.K. and Arora, K. 2007. Arsenic-induced root growth inhibition in mung bean (Phaseolus aureus Roxb.) is due to oxidative stress resulting from enhanced lipid peroxidation. Plant Growth Regulation, 53: 65-73.

Singh, R.; Gautam, N.; Mishra, A.; Gupta, R. (2011): Heavy metals and living systems: An overview. Indian Journal of Pharmacology, 43: 246.

Sridhar, B.B.M., Diehl, S.V., Han, F.X., Monts, D.L. and Su, Y. 2005. Anatomical changes due to uptake and accumulation of $\mathrm{Zn}$ and $\mathrm{Cd}$ in Indian mustard (Brassica juncea). Environmental and Experimental Botany, 54: 131-141.

Stevovic, S., Vesna, S.M. and Dusica, C. 2010. Environmental impact on morphological and anatomical structure of Tansy. African Journal of Biotechnology, 16(9): 2413-2421.

Sumiahadi, A. and Acar, R. 2018. A review of phytoremediation technology: heavy metals uptake by plants. Earth Environmental Science, 142: 012023.

Tiwari S. and Lata C. (2018) Heavy Metal Stress, Signaling, and Tolerance Due to PlantAssociated Microbes: An Overview. Frontiers in Plant Science, 9: 452.

Tran, T.A., Vassileva, V., Petrov, P. and Popova, L.P. 2013. Cadium-induced structural disturbances in Psium sativum leaves are alleviated by nitric oxide. Turkish Journal of Botany, 37: 698-707.

Xiong, T., Leveque, T., Shahid, M., Foucault, Y., Mombo, S., and Dumat, C. 2014. Lead and cadmium phytoavailability and human bioaccessibility for vegetables exposed to soil or atmospheric pollution by process ultrafine particles. Journal of Environmental Quality, 43:1593-1600.

Zhao, F.J., Lombi, E., Breedon, T. and McGrath, S.P. 2000. Zinc hyperaccumulation and cellular distribution in Arabidopsis halleri. Plant Cell and Environmental Physiology, 23: 507-514. 